Disponível em:

http://editora.unoesc.edu.br/index.php/race

Race, Joaçaba, v. 14, n. 2, p. 737-768, maio/ago. 2015

\title{
REMUNERAÇÃO VARIÁVEL BASEADA NO PAGAMENTO DE AÇÕES: UM ESTUDO DE EVIDENCIAÇÃO DAS INFORMAÇÕES RE- QUERIDAS PELO CPC 10 (R1) APLICADO EM EMPRESAS BRASILEIRAS
}

The variable remuneration based on actions payment: disclosure study of the information required by CPC 10 (R1) applied to Brazilian companies

Amanda Mendieta Larini

E-mail: amandalarini@hotmail.com Graduanda em Ciências Contábeis pela Universidade Federal de Santa Catarina.

Joice Denise Schäfer

E-mail: schafer.joice@gmail.com Graduada em Ciências Contábeis pela Universidade Estadual do Oeste do Paraná; mestranda em Contabilidade pela Universidade Federal de Santa Catarina.

Priscila Alano da Rosa

E-mail: priscilaalano@gmail.com Graduada em Ciências Contábeis pela Universidade Federal de Santa Catarina. mestranda em Contabilidade pela Universidade Federal de Santa Catarina.

Luiz Felipe Ferreira

E-mail: luiz.felipe@ufsc.br

Doutor em Engenharia Ambiental pela Universidade Federal de Santa Catarina;

Mestre em Administração pela Universidade Federal de Santa Catarina; Professor adjunto II no Departamento de Ciências Contábeis da Universidade Federal de Santa Catarina; Professor do Programa de Pós-graduação em Contabilidade da

Universidade Federal de Santa Catarina;

Endereço para contato: Campus Universitário, s/n, Trindade, Caixa Postal 476, 88010-970, Florianópolis, Santa Catarina, Brasil.

Artigo recebido em 23 de setembro de 2014. Aceito em 23 de janeiro de 2015. 
Amanda Mendieta Larini et al.

Resumo

As entidades buscam formas de incentivo aos funcionários, aos gestores e aos administradores por meio do processo de remuneração estratégica com o intuito de retê-los em suas organizações. Este estudo teve por objetivo identificar na listagem das 150 melhores empresas para se trabalhar, segundo a Revista Você S/A, o cumprimento do Comitê de Pronunciamentos Contábeis (CPC) 10 (R1), no item 45, que discorre sobre os procedimentos para a divulgação das informações nas demonstrações financeiras das empresas de capital aberto optantes do plano de remuneração estratégica baseado em compra de ações. Referente às tipologias de delineamento, a pesquisa classifica-se como indutiva, quanto à lógica de pesquisa; descritiva, em relação ao objetivo; documental, quanto aos procedimentos; e, qualitativa, quanto à abordagem do problema. Os resultados apontam que as empresas estão em concordância com o pronunciamento técnico CPC 10 (R1) no que diz respeito à evidenciação das informações referentes à opção de ações. Palavras-chave: Opção de compra de ações. Employee stock option plans. CPC 10 (R1). Disclosure.

\section{The variable remuneration based on actions payment: disclosure study of the information required by CPC 10 (R1) applied to Brazilian companies}

\section{Abstract}

In order to retain employees, managers and directors business entities seek to provide incentives to personnel through the process of strategic compensation. This study aimed to establish the degree of fulfillment of the Brazilian accounting pronouncement CPC 10 (R1), Item 45, which outlines the procedures for publicly traded companies' financial reporting on strategic compensation plans based on the purchase of shares. The sample is made up of the firms listed as the 150 best companies to work for in Brazil, according to the magazine Você $S / A$. The present work is classified as inductive, as per its reasoning method; descriptive, in terms of its goal; documentary, in respects to its procedures; and qualitative, for its approach to the research problem. The results indicate that companies in the sample comply with the CPC $10(R 1)$ in regards to the disclosure of information as to employee and manager purchasing of stock option.

Keywords: Stock option. Employee stock option plans. CPC 10 (R1). Disclosure.

\section{INTRODUÇÃO}

No Brasil, o Comitê de Pronunciamentos Contábeis (CPC 10) apresenta um conjunto de normas que devem ser seguidas pelas empresas na utilização do pagamento de ações, com o intuito de estabelecer os procedimentos para o reconhecimento e para a divulgação das operações nas demonstrações contábeis. Estudos anteriores como o de Marcon e Godo (2004), Nunes e Marques (2005), Galdi e Carvalho (2006), Nunes 
(2008), Pereira e Esperança (2009) e Madrid, Ochovo e Peñalver (2010) abordaram a utilização, bem como as normas que regem a opção por ações.

As empresas utilizaram por um longo período o sistema de remuneração fixa, ou funcional, baseado nas atividades e responsabilidades de cada função. No entanto, o uso de opções de ações executivas tem crescido consideravelmente ao longo das últimas décadas (BROCKMAN; MARTIN; PUCKETT, 2010) e apresenta inserção, inclusive, nas empresas brasileiras, conforme estudos de Perobelli (2003), Nunes e Marques (2005) e Marquart (2009). Isso porque o perfil do mercado tem exigido mudanças por parte das organizações, com maior controle no resultado e constante avaliação de seu desempenho. Com isso, os colaboradores passaram a ser avaliados com base nos resultados e, consequentemente, remunerados por um sistema estratégico, no qual se beneficiam diante do bom desempenho da organização (WOOD JÚNIOR; PICARELLI FILHO, 2004).

Para atrair profissionais, as organizações tendem a utilizar-se de remuneração indireta para garantir a satisfação deles e mantê-los leais (NUNES; MARQUES, 2005; GALDI; CARVALHO, 2006), bem como buscar um alinhamento das atitudes e dos comportamentos dos funcionários com os objetivos da organização; mas é necessário que o sistema de remuneração esteja estruturado adequadamente (DIAS; CUNHA; MÁRIO, 2009; BROCKMAN; MARTIN; PUCKETT, 2010; VICTOR; TERRA; SCHIEHLL, 2013), caso contrário, os executivos podem apresentar melhoras na divulgação de informações da empresa no exercício em que pretendem liquidar suas ações com o objetivo de obter maior remuneração (ALI, 2014). Outro fator importante, que impulsionou a alavancagem da remuneração variável, é que esta proporciona um tratamento fiscal favorável, ocasionando reduções em seus custos (HUDDART; LANG, 1996; STREET; CEREOLA, 2004).

As empresas estão aderindo ao plano de opção de compra de ações (stock options), por ser um meio de incentivo com baixo custo e grandes retornos. Como resultado desse plano de remuneração, os colaboradores passam a incluir-se como parte da gestão da empresa, o que contribui para a motivação e para o evidente aumento de produção, o que gera maiores lucros para as organizações. Sua utilização resulta em produção extra, o que evidencia que os colaboradores estão se conscientizando de que parte do resultado será revertida em remuneração (KRAUTER, 2006).

Para Espahbodi et al. (2002), a disseminação da remuneração baseada em ações como um plano de incentivo não foi influenciada apenas pelo desejo das empresas de motivar os funcionários e conservar os desembolsos de caixa, mas também pelo fato de que nenhuma despesa precisa ser reconhecida, contudo, como 
o sistema de remuneração se tornou popular, a classe contábil passou a preocupar-se com a sua evidenciação de forma padronizada. Nesse sentido, no Brasil, o Comitê de Pronunciamentos Contábeis, seguindo o modelo de regulamentação estabelecido pelo Internacional Accounting Standards Board (IASB), constituiu o CPC 10.

Dias, Cunha e Mário (2009) realizaram uma pesquisa com o objetivo de comparar e analisar a divulgação das informações referentes aos planos de incentivos em opções de ações por empresas brasileiras de capital aberto pertencente aos níveis de governança da BM\&FBOVESPA nas demonstrações financeiras dos exercícios de 2007 e 2008, com o intuito de verificar se a publicação do CPC 10 culminou em um maior detalhamento de informações divulgadas em 2008 em relação ao ano 2007. Os resultados encontrados evidenciaram que, de forma geral, o nível de detalhamento das informações sobre planos de opções em ações por parte das empresas analisadas foi superior em 2008, após a publicação do CPC 10, quando comparado ao ano 2007.

Com o desígnio de realizar uma análise em períodos recentes, bem como comparar o nível de evidenciação de informação com os resultados apresentados na pesquisa de Dias, Cunha e Mario (2009), o presente estudo buscou verificar a adoção da remuneração variável com pagamento baseado em ações por empresas brasileiras de capital aberto, observando o cumprimento dos procedimentos estabelecidos pelo CPC 10 (R1), no período de 2010 a 2012, por meio da seguinte pergunta de pesquisa: Os preceitos de divulgação estabelecidos pelo CPC 10 (R1) são adotados na elaboração das demonstrações contábeis das empresas brasileiras de capital aberto?

Esta pesquisa não teve como objetivo esgotar o estudo sobre a utilização do plano de remuneração variável com base na compra de ações, apenas se propõe a identificar, por meio de um arcabouço teórico baseado na literatura correlata e a confrontação com as informações divulgadas pelas empresas quanto aos requisitos do pronunciamento CPC 10 (R1), item n. 45.

\section{REFERENCIAL TEÓRICO}

A presente seção apresenta-se dividida em seis subseções principais: sistemas de remuneração estratégica na qual são apresentados conceitos sobre o tema, bem como as classes de remuneração que se adéquam a ele; remuneração por resultado variável, em que é apresentado o sistema de remuneração variável e seus objetivos; remuneração por opção de ações, na qual são apresentados os principais conceitos e o funcionamento desta remuneração, que é o tema central da presente pesquisa; 
recomendações do CPC 10 (R1), na qual são abordados os aspectos instituídos pelo pronunciamento técnico no que se refere ao pagamento por opção de ações e seu objetivo, mensuração e a forma de evidenciação; disclosure dos pagamentos baseados em ações, que trata da mensuração e a forma de evidenciação da remuneração por opção de ações, com base no CPC 01; e estudos anteriores, em que são apresentadas as produções científicas, relacionadas ao assunto deste estudo.

\section{1 SISTEMA DE REMUNERAÇÃO ESTRATÉGICA}

Um marco para a expansão dos sistemas estratégicos de remuneração foi a separação entre a propriedade e a gestão, ou seja, os proprietários passaram a delegar a responsabilidade da tomada de decisões a um agente, que pode não ter os mesmos objetivos que o principal, tomando, dessa forma, decisões que podem não representar a opinião do proprietário. Tal questão pode ser minimizada por meio de remunerações estratégicas, nas quais os gerentes são recompensados pelo resultado gerado à empresa, pois os incentiva a trabalhar pelos interesses da entidade como um todo (PEREIRA; ESPERANÇA, 2009; GALDI; CARVALHO, 2006; DIAS; CUNHA; MARIO, 2009; MARCON; GODO, 2004).

A tendência é a utilização de remuneração estratégica por parte das empresas com o objetivo de impulsionar os resultados de curto e longo prazo, visto que esse tipo de remuneração pode melhorar os retornos esperados, pois os colaboradores produzem mais e têm maior satisfação profissional (MARRAS, 2002).

Wood Júnior et al. (2000) apresentam sete formas de remuneração estratégica que têm crescido no mercado: remuneração funcional; remuneração por habilidade; competência; salário indireto; remuneração variável; previdência complementar; e as alternativas criativas. A participação acionária, uma das opções de remuneração variável, é o foco do presente estudo, portanto, será abordada detalhadamente nas próximas seções.

\section{2 REMUNERAÇÃO POR RESULTADO VARIÁVEL}

As empresas objetivam, comumente, transformar o esforço dos colaboradores em resultados, melhorando suas performances, sendo a remuneração baseada no desempenho uma das formas de fazê-lo. Para Beuren, Kaveski e Rigo (2014, p. 9), essa pode ser uma alternativa “[...] para garantir a obtenção de vantagem 
competitiva sustentável e alinhar os interesses de gestores e investidores, colaborando para suavizar os conflitos oferecidos em sistemas hierárquicos de remuneração”.

O Fluxograma 1 exemplifica a distribuição da remuneração estratégica em cinco grupos e situa a remuneração variável dentre eles.

Fluxograma 1 - Visão da Remuneração

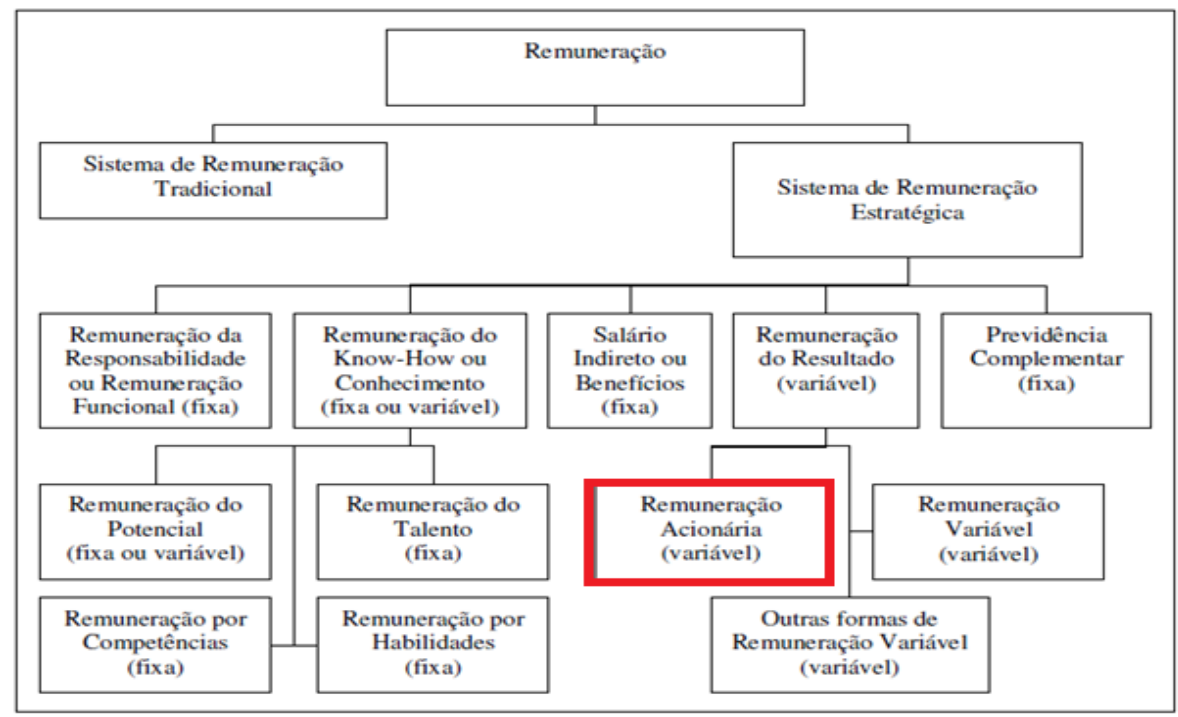

Fonte: Marquart (2009, p. 35).

Para Xavier (1999), a implementação de qualquer forma de remuneração variável tem como objetivo motivar os executivos, maximizando os retornos de longo prazo dos acionistas. Por essa razão, os colaboradores devem ser remunerados pelo valor de suas criações ou realizações. A finalidade, em sua maioria, é estimular a obtenção de resultados, superando as expectativas do mercado. Não obstante, Dias, Cunha e Mário (2009) afirmam que o principal objetivo desse tipo de remuneração é obter a atenção dos colaboradores; conforme os autores, as organizações utilizam vários métodos para fidelizar esses profissionais. Cada uma dessas ferramentas têm um tipo de abordagem diferente para tentar satisfazê-los e mantê-los no seu quadro de funcional, podendo, assim, usufruir de toda a sua capacidade intelectual por um período de tempo.

A remuneração por resultado se baseia em resultados qualitativos e quantitativos, verificando o valor de mercado e se as metas estabelecidas foram atingidas (HIPÓLITO, 2001), ou seja, o pagamento dos colaboradores é vinculado aos objetivos e metas da empresa, o que, conforme Wood Júnior et al. (2000), é a melhor maneira de se obter bons resultados e satisfação dos envolvidos. 


\section{3 REMUNERAÇÃO POR OPÇÃO DE AÇÕES}

No começo da década de 1990, as empresas consideraram as opções de ações parte representativa da remuneração; passados dez anos, as opções de ações constituíam mais da metade da remuneração total dos altos executivos das maiores empresas dos Estados Unidos (OLIVEIRA, 2004). No Brasil, segundo Carvalho Neto (2001), foi constatada a primeira negociação expressiva no setor automobilístico em 1995.

A Legislação brasileira prevê, por meio da Lei n. 6.404, de 15 de dezembro de 1976, que dispõe sobre a Sociedade por Ações, em seu art. 168, parágrafo $3^{\circ}$, que

[...] a companhia, dentro do limite de capital autorizado, e de acordo com plano aprovado pela assembleia-geral, outorgue opção de compra de ações a seus administradores ou empregados, ou a pessoas naturais que prestem serviços à companhia ou à sociedade sob seu controle.

A Comissão de Valores Mobiliários (CVM), por sua vez, publicou em 2007 o Ofício- Circular/CVM/SNC/SEP n. 01/2007, “[...] no qual, entre vários outros assuntos, discriminou suas considerações sobre a matéria de remuneração por ações” (DIAS; CUNHA; MÁRIO, 2009, p. 32). No item 25.3 do referido ofício, a opção de ações como remuneração de empregados é definida como o direito adquirido pelo empregado para a aquisição de ações da companhia por um preço fixo e por determinado período. Conforme a Comissão de Valores Mobiliários (2007, p. 7), “[...] a lógica deste benefício é a expectativa que o preço das ações subirá e os empregados poderão comprá-la pelo exercício (compra) a um preço mais baixo que foi referenciado no momento da concessão e vendê-lo pelo preço corrente do mercado".

A opção de compra de ação refere-se à concessão de um direito de compra conferido pelas empresas aos seus empregados (KRAUTER, 2006). Inicialmente concedido apenas a funcionários do alto escalão, a remuneração por opção de ações passou a contemplar também "[...] gerentes e outros colaboradores das empresas, como um incentivo destinado a evitar perda de profissionais competentes" (MARCON; GODO, 2004, p. 73).

Conforme destacam Madrid, Ochovo e Peñalver (2010), a opção de ações surge como um inovador sistema de remuneração variável de longo prazo, que concede o direito (e não a obrigação) de compra de determinado número de ações a um preço preestabelecido. A adoção de tal método de remuneração teve como consequência resultado positivo para as entidades. As ações e opções de ações maximizam o bom comportamento, a motivação, e impulsionam altos níveis de desempenho dos funcionários (NUNES, 2008). 
Apesar da expansão da aplicação da remuneração variável por opção de compra de ações por empresas brasileiras, apenas em 2008 foram criadas normativas pelo Comitê de Pronunciamentos Contábeis (CPC) por meio do pronunciamento 10, o qual aborda a natureza jurídica da remuneração variável.

\section{4 RECOMENDAÇÕES DO CPC 10 (R1)}

O Comitê de Pronunciamentos Contábeis no ano 2008 emitiu o Pronunciamento Técnico CPC 10 - Pagamento baseado em Ações, aprovado pela CVM por intermédio da deliberação n. 562/2008. Quando criada, a deliberação visou atender às alterações no art. 177 da Lei n. 6.404/1976, que versa sobre a permanência dos registros contábeis e sobre os métodos e critérios que deveriam ser observados na escrituração das companhias que possuem opções de remuneração por ações.

Nos anos 2009 e 2010 ocorreu um processo de revisão em alguns itens pontuais de alguns CPCs. Essas alterações atingiram o pronunciamento 10, aprovado originalmente em 05 de dezembro de 2008. O texto do CPC 10, agora revisado, portanto, CPC 10 (R1), tem como objetivo instituir as regras para a evidenciação das transações com pagamento baseado em ações nas demonstrações contábeis,

[...] especificamente, exigindo-se que os efeitos das transações com pagamento baseado em ações estejam refletidos no resultado e no balanço patrimonial da entidade, incluindo despesas associadas com transações por meio das quais opções de ações são outorgadas a empregados. (COMITÊ DE PRONUNCIAMENTOS CONTÁBEIS, 2010, p. 3).

O foco da proposta de revisão do CPC 10 era de contemplar alterações feitas pelo IASB, as orientações contidas no ICPC 04 e ICPC 05 (IFRIC 8 e IFRIC 11) e as compatibilizações de texto visando não deixar dúvidas sobre a intenção do pronunciamento que é produzir os mesmos reflexos contábeis que a aplicação do IFRS 2. As modificações propostas, porém, não alteraram a essência do pronunciamento original.

Quanto ao alcance previsto para o pronunciamento, a entidade deve aplicá-lo para contabilizar todas as transações cujos pagamentos sejam baseados em ações. Em relação à visão geral do pronunciamento, segundo o Comitê de Pronunciamentos Contábeis (2010), ações, opções de ações ou outros instrumentos patrimoniais são outorgados aos empregados sendo parte integrante da sua remuneração, de forma adicional ao salário ou outros benefícios. Por vezes, as ações e opções de ações 
também podem ser outorgadas como parte de acordo de pagamento de bônus, em vez de serem consideradas parte da remuneração básica dos empregados.

A entidade deve mensurar as transações que envolvam pagamento baseado em ações líquidas pela entrega de instrumentos patrimoniais, bem como “[...] produtos ou serviços recebidos, e o aumento correspondente no patrimônio líquido, de forma direta, pelo valor justo dos produtos ou serviços recebidos, a menos que o valor justo não possa ser estimado com confiabilidade". (Comitê de Pronunciamentos Contábeis, 2010, p. 6). Caso isso ocorra, a entidade pode fazêlo de forma indireto, ou seja, tomar como base o valor justo dos instrumentos patrimoniais concedidos. Ao se utilizar do reconhecimento indireto, a empresa deverá mensurar o valor justo dos instrumentos patrimoniais na data de outorga (COMITÊ DE PRONUNCIAMENTOS CONTÁBEIS, 2010).

O CPC 10 (R1) concentra-se, portanto, em orientações para a regulamentação do pagamento baseado na opção por ações. Tal remuneração é avaliada pelo CPC (2010, p. 7) como um "[...] incentivo para que os empregados permaneçam nos quadros da entidade ou de prêmio por seus esforços na melhoria do desempenho da entidade". Percebe-se que ao adotar este sistema a empresa procura beneficiar seus empregados, mas também visa obter melhores resultados nos indicadores financeiros e econômicos, propiciando caso a caso a valorização de suas ações, o que amplia a possibilidade das empresas na manutenção e/ou adesão do plano de remuneração por ações.

\section{5 DISCLOSURE DOS PAGAMENTOS BASEADOS EM AÇÕES}

O texto do CPC 10 (R1) traz as informações necessárias referentes à divulgação das informações sobre o pagamento baseado em ações. Conforme o CPC (2010, p. 19), a entidade deve "[...] divulgar informações que permitam aos usuários das demonstrações contábeis entender a natureza e a extensão dos acordos com pagamento baseado em ações que existiram durante o período”.

Como forma de padronizar a publicação das informações acerca dos pagamentos baseados em ações, o pronunciamento dispõe no item seguinte a forma como essas informações devem ser divulgadas, de maneira que se cumpra o prescrito anteriormente. Conforme o CPC (2010, p. 19-20), devem ser divulgadas as informações descritas no Quadro 1: 
Quadro 1 - CPC 10 (R1): item divulgação e seus subitens

\begin{tabular}{|c|c|}
\hline Item & Subitem \\
\hline \multirow{3}{*}{$\begin{array}{l}\text { a) Descrição de cada tipo de acordo com } \\
\text { pagamento baseado em ações que vigorou em } \\
\text { algum momento do período, incluindo, para } \\
\text { cada acordo, os termos e as condições gerais. }\end{array}$} & 1) Requisitos de aquisição de direito; \\
\hline & 2) Prazo máximo das opções outorgadas; \\
\hline & $\begin{array}{l}\text { 3) Método de liquidação (caixa ou ins- } \\
\text { trumentos patrimoniais). }\end{array}$ \\
\hline \multirow{7}{*}{$\begin{array}{l}\text { b) A quantidade e o preço médio ponderado } \\
\text { de exercício das opções para cada um dos } \\
\text { seguintes grupos. }\end{array}$} & 1) Em circulação no início do período; \\
\hline & 2) Outorgadas durante o período; \\
\hline & $\begin{array}{l}\text { 3) Com direito prescrito durante o } \\
\text { período; }\end{array}$ \\
\hline & 4) Exercidas durante o período; \\
\hline & 5) Expiradas durante o período; \\
\hline & 6) Em circulação no final do período; \\
\hline & 7) Exercíveis no final do período. \\
\hline $\begin{array}{l}\text { c) Para as opções de ações exercidas durante o } \\
\text { período, o preço médio ponderado das ações } \\
\text { na data do exercício. }\end{array}$ & $\begin{array}{l}\text { 1) Preço médio ponderado na data do } \\
\text { exercício. }\end{array}$ \\
\hline $\begin{array}{l}\text { Se as opções forem exercidas em base regular } \\
\text { durante todo o período, a entidade pode, em } \\
\text { vez disso, divulgar o preço médio ponderado } \\
\text { das ações durante o período. }\end{array}$ & $\begin{array}{l}\text { 2) Preço médio ponderado durante o } \\
\text { período. }\end{array}$ \\
\hline $\begin{array}{l}\text { d) Para as opções de ações em circulação no } \\
\text { final do período, a faixa de preços de exercício } \\
\text { e a média ponderada da vida contratual rema- } \\
\text { nescente. Se a faixa de preços de exercício for } \\
\text { muito ampla, as opções em circulação devem } \\
\text { ser divididas em faixas que possuam um } \\
\text { significado para avaliar a quantidade e o prazo } \\
\text { em que ações adicionais possam ser emitidas } \\
\text { e o montante em caixa que possa ser recebido } \\
\text { por ocasião do exercício dessas opções. }\end{array}$ & \\
\hline
\end{tabular}

Fonte: adaptado do Comitê de Pronunciamentos Contábeis (2010).

A informação divulgada pelas entidades deve permitir a seus usuários o entendimento de como foi mensurado o valor justo dos produtos ou serviços recebidos ou outorgados durante o período. Se a entidade tiver mensurado o valor justo dos produtos ou serviços recebidos indiretamente, tomando por referência o valor justo dos instrumentos patrimoniais outorgados, a entidade deve divulgar no mínimo o que segue, segundo o CPC (2010): 
a) Quando se tratar de ações outorgadas no período deve ser divulgado o valor justo médio ponderado delas na data de mensuração, informando o modelo de precificação utilizado, bem como seus dados de entrada (volatilidade esperada das ações, dividendos esperados, taxa de juros, entre outros). A empresa deverá informar ainda como foi determinada a volatilidade das ações, se foi e como foi incorporada alguma característica, como, por exemplo, uma condição de mercado, e, por último, a opção outorgada para a mensuração do valor justo.

b) Quando se tratar de instrumentos patrimoniais outorgados diferentes de ações a empresa deve divulgar a quantidade e o valor justo médio ponderado, também na data da mensuração, informando como foi mensurado o valor justo (caso não tenha sido o preço de mercado observável). Caso os dividendos esperados ou qualquer outra característica dos instrumentos patrimoniais outorgados tenham sido incorporados na mensuração do valor justo, a empresa deverá justificar de que forma isso ocorreu.

Caso os acordos para a remuneração baseada em ações tenham sido alterados durante o período, a entidade deverá explicar os motivos, os resultados dessas modificações e como o valor justo foi mensurado. Se a entidade mensurar diretamente o valor justo dos produtos ou serviços recebidos durante o período, deverá divulgar como ele foi determinado. Se ela refutar as premissas contidas nos itens, deverá explicar o porquê de tal refuto.

Devem ser divulgadas informações que permitam aos usuários entenderem "[...] os efeitos das transações com pagamento baseado em ações sobre os resultados do período da entidade e sobre sua posição patrimonial e financeira" (COMITÊ DE PRONUNCIAMENTOS CONTÁBEIS, 2010, p. 18). Para isso, o total das despesas oriundas das transações da remuneração baseada em ações que não se qualificaram como ativas, mas foram reconhecidas imediatamente como despesas, deve ser divulgado separadamente das transações de pagamentos baseados em ações liquidadas em instrumentos patrimoniais, e os passivos decorrentes de tais transações devem apresentar o saldo contábil no final do período e o “[...] valor intrínseco total no final do período dos passivos para os quais os direitos da contraparte ao recebimento em caixa ou em outros ativos tenham sido adquiridos (hadvested)" (COMITÊ DE PRONUNCIAMENTOS CONTÁBEIS, 2010, p. 19).

Caso as informações que forem divulgadas pelas empresas não satisfaçam os princípios contidos no pronunciamento, a entidade deverá divulgar informações 
adicionais que possam atender às necessidades de atendimento dos itens propostos, para o entendimento dos usuários contábeis (DIAS; CUNHA; MÁRIO, 2009).

\section{6 ESTUDOS CORRELATOS}

A revisão da literatura foi baseada nas Scientific Electronic Library SPELL e SCIELO, com a utilização das palavras-chave, opções de ações e stock options e na base internacional SCOPUS, com as palavras-chave stock options e disclosure. No Quadro 2 são expostos os artigos alinhados com o tema, que retornaram de tais pesquisas.

Quadro 2 - Estudos Correlato

\begin{tabular}{|c|c|c|c|c|}
\hline Base & $\begin{array}{l}\text { Revista/ } \\
\text { Ano }\end{array}$ & Autores & Objetivos & Resultados \\
\hline \multirow{5}{*}{ 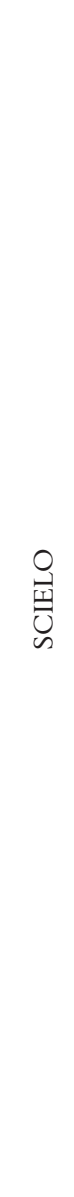 } & $\begin{array}{l}\text { Revista Con- } \\
\text { tabilidade e } \\
\text { Finanças }\end{array}$ & $\begin{array}{l}\text { Nunes e } \\
\text { Marques }\end{array}$ & $\begin{array}{l}\text { Verificar se há distinção entre } \\
\text { as Demonstrações Contábeis } \\
\text { no Mercado de Ações local } \\
\text { e o Internacional, referente } \\
\text { às transações de Opções de } \\
\text { Ações. }\end{array}$ & $\begin{array}{l}\text { Observou-se que no mercado } \\
\text { local, há envio das informações } \\
\text { referentes a opções de compra de } \\
\text { ações, mas não há padronização } \\
\text { das informações básicas, confor- } \\
\text { me parecer da CVM. No merca- } \\
\text { do Internacional há padronização } \\
\text { no envio de informações para } \\
\text { SEC, conforme SFAS n. } 123 \text {. }\end{array}$ \\
\hline & $\begin{array}{l}\text { Revista Con- } \\
\text { tabilidade e } \\
\text { Finanças } \\
2006\end{array}$ & $\begin{array}{l}\text { Galdi e } \\
\text { Carvalho }\end{array}$ & $\begin{array}{l}\text { Analisar o arcabouço conceitu- } \\
\text { al do SFAS } 123 \text { revisado. }\end{array}$ & $\begin{array}{l}\text { Observaram que a principal mu- } \\
\text { dança ocorrida entre o SAFS } 123 \\
\text { original para o SAFS } 123 \text { revisado } \\
\text { é referente tanto ao reconhe- } \\
\text { cimento obrigatório quanto ao } \\
\text { impacto causado na remuneração } \\
\text { em opções de ações nas Demons- } \\
\text { trações Contábeis. }\end{array}$ \\
\hline & $\begin{array}{l}\text { Pensar Con- } \\
\text { tábil } \\
2009\end{array}$ & $\begin{array}{l}\text { Dias, Cunha } \\
\text { e Mário }\end{array}$ & $\begin{array}{l}\text { Comparar a divulgação das } \\
\text { informações referentes aos } \\
\text { planos de incentivos em } \\
\text { opções de ações de empresas } \\
\text { brasileiras após o CPC } 10 \text { no } \\
\text { ano } 2008 \text { em relação a } 2007 .\end{array}$ & $\begin{array}{l}\text { Constataram que após o CPC } \\
\text { 10, o nível de evidenciação de } \\
\text { informações referente aos planos } \\
\text { de opções de ações melhorou nas } \\
\text { empresas analisadas. }\end{array}$ \\
\hline & \begin{tabular}{|l} 
Revista \\
Portuguesa e \\
Brasileira de \\
Gestão \\
2009 \\
\end{tabular} & $\begin{array}{l}\text { Pereira e } \\
\text { Esperança }\end{array}$ & $\begin{array}{l}\text { Verificar em } 102 \text { empresas } \\
\text { portuguesas a remuneração } \\
\text { variável com compras de ações } \\
\text { de empresas familiares e de } \\
\text { capital aberto. }\end{array}$ & $\begin{array}{l}\text { Concluíram que as empresas de } \\
\text { capital aberto tendem a remune- } \\
\text { rar mais os funcionários com a } \\
\text { remuneração variável do que as } \\
\text { empresas familiares. }\end{array}$ \\
\hline & $\begin{array}{l}\text { Contaduria y } \\
\text { Administra- } \\
\text { ción } \\
2010\end{array}$ & $\begin{array}{l}\text { Madrid, } \\
\text { Ochovo e } \\
\text { Peñalver }\end{array}$ & $\begin{array}{l}\text { Observar o problema da } \\
\text { contabilização de Opções de } \\
\text { Ações que é regido por normas } \\
\text { internacionais considerando o } \\
\text { método de valor justo. }\end{array}$ & $\begin{array}{l}\text { Observaram que as normas inter- } \\
\text { nacionais não preveem a técnica } \\
\text { de avaliação a ser utilizada com as } \\
\text { opções de ações. }\end{array}$ \\
\hline
\end{tabular}




\begin{tabular}{|c|c|c|c|c|}
\hline \multirow{3}{*}{$\stackrel{\overrightarrow{3}}{\frac{1}{n}}$} & $\begin{array}{l}\text { Revista de } \\
\text { Administra- } \\
\text { ção } 2004\end{array}$ & $\begin{array}{l}\text { Marcon e } \\
\text { Godo }\end{array}$ & $\begin{array}{l}\text { Identificar a correlação entre } \\
\text { a utilização de programas de } \\
\text { remuneração por stock options } \\
\text { e o desempenho financeiro das } \\
\text { empresas. }\end{array}$ & $\begin{array}{l}\text { Concluiu-se que grande parte } \\
\text { das empresas com remuneração } \\
\text { variável apresentaram maior } \\
\text { desempenho econômico. }\end{array}$ \\
\hline & $\begin{array}{l}\text { Revista de } \\
\text { Administra- } \\
\text { ção e Con- } \\
\text { tabilidade da } \\
\text { Unisinos } \\
2008\end{array}$ & Nunes & $\begin{array}{l}\text { Estudar a evolução de compor- } \\
\text { tamento das companhias, por } \\
\text { meio das Demonstrações Con- } \\
\text { tábeis, em relação à concessão } \\
\text { de opções de ações. }\end{array}$ & $\begin{array}{l}\text { Constataram que as informações } \\
\text { enviadas à CVM não seguem o } \\
\text { padrão exigido por ela. As empre- } \\
\text { sas também falham ao contabi- } \\
\text { lizar esse ativo sem considerar } \\
\text { cálculos de precificação. }\end{array}$ \\
\hline & $\begin{array}{l}\text { Contaduria y } \\
\text { Administra- } \\
\text { ción } \\
2010\end{array}$ & $\begin{array}{l}\text { Madrid, } \\
\text { Ochovo e } \\
\text { Peñalver }\end{array}$ & $\begin{array}{l}\text { Observar o problema da } \\
\text { contabilização de Opções de } \\
\text { Ações que é regido por normas } \\
\text { internacionais considerando o } \\
\text { método de valor justo. }\end{array}$ & $\begin{array}{l}\text { Observaram que as normas inter- } \\
\text { nacionais não preveem a técnica } \\
\text { de avaliação a ser utilizada com as } \\
\text { opções de ações. }\end{array}$ \\
\hline \multirow{3}{*}{ 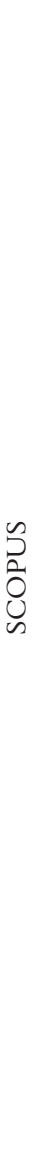 } & $\begin{array}{l}\text { Journal of } \\
\text { Accounting } \\
\text { and Econo- } \\
\text { mics } 1996\end{array}$ & $\begin{array}{l}\text { Huddart e } \\
\text { Lang }\end{array}$ & $\begin{array}{l}\text { Descrever o comportamento } \\
\text { de exercício de mais de } 50.000 \\
\text { funcionários de oito corpo- } \\
\text { rações que detêm, em longo } \\
\text { prazo, opções de ações do } \\
\text { empregador. }\end{array}$ & $\begin{array}{l}\text { Em geral, os trabalhadores sacri- } \\
\text { ficam uma parcela significativa do } \\
\text { valor potencial pelo exercício de } \\
\text { opções antes do vencimento. Esse } \\
\text { fato e a relação entre exercício e } \\
\text { preço das ações sugerem a aver- } \\
\text { são dos funcionários ao risco. }\end{array}$ \\
\hline & $\begin{array}{l}\text { Journal of } \\
\text { Accounting } \\
\text { and Econo- } \\
\text { mics } 2002\end{array}$ & $\begin{array}{l}\text { Espahbodi, } \\
\text { Espahbodi, } \\
\text { Rezaee e } \\
\text { Tehranian }\end{array}$ & $\begin{array}{l}\text { Analisar a reação do preço das } \\
\text { ações relacionadas com os pro- } \\
\text { nunciamentos contábeis refe- } \\
\text { rentes à remuneração baseada } \\
\text { em ações e avaliar a relevância } \\
\text { do valor do reconhecimento e } \\
\text { divulgação dessas informações } \\
\text { nos relatórios financeiros. }\end{array}$ & $\begin{array}{l}\text { O impacto do preço das ações } \\
\text { está positivamente relacionado } \\
\text { à existência de prejuízo fiscal } \\
\text { a frente, a extensão do uso de } \\
\text { opções de ações (como refletido } \\
\text { por seu efeito sobre o lucro } \\
\text { por ação), e lucros acumulados } \\
\text { relativos à restrição da dívida; e } \\
\text { negativamente relacionada com o } \\
\text { ruído no desempenho do preço } \\
\text { das ações, fluxos de caixa livres } \\
\text { sobre os ativos totais e tamanho } \\
\text { da empresa. }\end{array}$ \\
\hline & $\begin{array}{l}\text { Journal of } \\
\text { International } \\
\text { Accounting, } \\
\text { Auditing \& } \\
\text { Taxation } 2004\end{array}$ & $\begin{array}{l}\text { Street e } \\
\text { Cereola }\end{array}$ & $\begin{array}{l}\text { Analisar as divulgações de } \\
\text { opções de ações previstas } \\
\text { no Form } 20-F \text { pelas empre- } \\
\text { sas australianas, britânicas, } \\
\text { canadenses, francesas, alemãs, } \\
\text { japonesas e irlandesas. }\end{array}$ & $\begin{array}{l}\text { Os resultados indicam que o } \\
\text { impacto médio de reconheci- } \\
\text { mento de despesa com lucro por } \\
\text { ação diluído será aproximada- } \\
\text { mente } 40 \% \text { e será material em } \\
\text { um nível de } 5 \% \text { para a maioria } \\
\text { das empresas. Em média, a } \\
\text { despesa anual reconhecida será } \\
\text { de aproximadamente } 15 \% \text { de } \\
\text { patrimônio líquido inicial. Para } \\
\text { a maioria das empresas, a carga } \\
\text { representa menos de } 1 \% \text { do início } \\
\text { da equivalência patrimonial. }\end{array}$ \\
\hline
\end{tabular}




\begin{tabular}{|c|c|c|c|c|}
\hline \multirow{5}{*}{$\begin{array}{l}n \\
2 \\
0 \\
0 \\
n\end{array}$} & $\begin{array}{l}\text { Journal of } \\
\text { Corporate } \\
\text { Finance } 2009\end{array}$ & $\begin{array}{l}\text { Brockman, } \\
\text { Martin } \\
\text { ePuckett }\end{array}$ & $\begin{array}{l}\text { Investigar a divulgação } \\
\text { voluntária de informações e } \\
\text { sua relação com o período de } \\
\text { execução de ações dos CEOs. }\end{array}$ & $\begin{array}{l}\text { O estudo fornece evidências de } \\
\text { que divulgações oportunistas } \\
\text { (notícias boas) estão positiva- } \\
\text { mente relacionadas ao valor das } \\
\text { opções de ações exercidas pelos } \\
\text { CEOs. Embora a Lei Sarbanes- } \\
\text {-Oxley (SOX) tenha reduzido } \\
\text { esse tipo de comportamento, não } \\
\text { o eliminou por completo. }\end{array}$ \\
\hline & $\begin{array}{l}\text { Journal of } \\
\text { Management } \\
\text { \& Governan- } \\
\text { ce } 2010\end{array}$ & $\begin{array}{l}\text { Melis e } \\
\text { Carta }\end{array}$ & $\begin{array}{l}\text { Explorar o impacto da obriga- } \\
\text { toriedade da adoção do IFRS } \\
2 \text { sobre a contabilização de } \\
\text { remuneração baseada em ações } \\
\text { pelas empresas italianas, não } \\
\text { financeiras, cotadas na bolsa. }\end{array}$ & $\begin{array}{l}\text { Os resultados evidenciaram } \\
\text { que a mudança na regulação da } \\
\text { contabilidade tem contribuído } \\
\text { para revelar o "verdadeiro" custo } \\
\text { da remuneração baseada em } \\
\text { ações aos acionistas minoritários } \\
\text { e outros investidores. }\end{array}$ \\
\hline & $\begin{array}{l}\text { Accounting \& } \\
\text { Finance } 2010\end{array}$ & $\begin{array}{l}\text { Nelson, } \\
\text { Gallery e } \\
\text { Percy }\end{array}$ & $\begin{array}{l}\text { Examinar a natureza e a } \\
\text { extensão da conformidade com } \\
\text { os requisitos de divulgação de } \\
\text { opções de ações em relatórios } \\
\text { anuais das empresas austra- } \\
\text { lianas e verificar como os } \\
\text { mecanismos de governança } \\
\text { corporativa influenciam no } \\
\text { cumprimento da divulgação. }\end{array}$ & $\begin{array}{l}\text { Os resultados apontam um } \\
\text { aumento progressivo da confor- } \\
\text { midade global dos requisitos de } \\
\text { divulgação das opções de ações de } \\
2001 \text { a } 2004 \text {. Fatores associados à } \\
\text { boa governação interna e externa } \\
\text { são itens que contribuem para a } \\
\text { melhoria da conformidade. }\end{array}$ \\
\hline & $\begin{array}{l}\text { Journal of } \\
\text { Management } \\
\text { \& Gover- } \\
\text { nance } \\
2013\end{array}$ & $\begin{array}{l}\text { Victor, Terra } \\
\text { e Schiell }\end{array}$ & $\begin{array}{l}\text { Investigar se a divulgação } \\
\text { voluntária dos planos de opção } \\
\text { de ações das empresas brasilei- } \\
\text { ras está associada à estrutura de } \\
\text { governança corporativa. }\end{array}$ & $\begin{array}{l}\text { Concluiu-se que as empresas } \\
\text { abertas brasileiras que utilizam } \\
\text { planos de opção de açóes como } \\
\text { um mecanismo de compensação } \\
\text { de longo prazo divulgam relativa- } \\
\text { mente pouco sobre eles. }\end{array}$ \\
\hline & $\begin{array}{l}\text { Journal of } \\
\text { Applied Busi- } \\
\text { ness Research } \\
2014\end{array}$ & Ali & $\begin{array}{l}\text { Analisar um conjunto de } \\
\text { características de governança } \\
\text { corporativa que influenciam } \\
\text { a qualidade da divulgação em } \\
\text { um contexto de conflitos entre } \\
\text { principal-principal e a má } \\
\text { proteção aos investidores. }\end{array}$ & $\begin{array}{l}\text { A divulgação está negativamente } \\
\text { associada à concentração da pro- } \\
\text { priedade, os principais direitos de } \\
\text { voto dos acionistas, a existência } \\
\text { de duplo direito de voto e de } \\
\text { controle familiar e positivamente } \\
\text { com a qualidade da divulgação e } \\
\text { da existência de opção de ações } \\
\text { para os executivos visto que esse } \\
\text { mecanismo desempenha um } \\
\text { papel chave na transparência } \\
\text { corporativa. }\end{array}$ \\
\hline
\end{tabular}

Fonte: os autores.

Os estudos apresentados no Quadro 2, correspondentes às bases SPELL, SCIELO e SCOPUS, demonstram a preocupação com a forma de contabilização 
da remuneração por stock options. Os autores comentam que as empresas utilizam os padrões exigidos pela Securities and Exchange Commission (SEC) e Comissão de Valores Mobiliários (CVM), ao informarem em suas Demonstrações Contábeis esse tipo de remuneração. Outra preocupação dos estudos é quanto às normas de divulgação de informações sobre a remuneração por stock options; há no Financial Accouting Standards Board (FASB) e no International Accounting Standars Board (IASB) normas a respeito da remuneração por opções de ações e no Brasil, antes da elaboração do CPC 10, não havia regulamentação.

A maior parte dos estudos da base de dados SCOPUS, por sua vez, analisa o plano de compra de ações sob os aspectos da governança corporativa, por meio de fatores que podem influenciar a utilização e a correta divulgação desse sistema de remuneração.

\section{METODOLOGIA}

Nesta seção, são expostos o enquadramento metodológico da pesquisa, os procedimentos para revisão do referencial teórico, além da caracterização da população e a amostra e os procedimentos utilizados para coleta e tratamento dos dados.

\section{1 ENQUADRAMENTO METODOLÓGICO}

Uma pesquisa, segundo Gil (1999 p. 1), pode ser definida: “[...] como um procedimento racional e sistemático que tem como objetivo procurar respostas aos problemas propostos". A trajetória metodológica da pesquisa é deliberada com base na problemática formulada (BEUREN, 2006). A caracterização metodológica da pesquisa foi enquadrada conforme quatro aspectos: natureza dos objetivos, lógica de pesquisa, abordagem do problema e coleta de dados.

No que compete à natureza dos objetivos, a pesquisa enquadra-se como descritiva, pois se buscou descrever aspectos e características de determinada população, sem o intuito de compreensão do porquê de tal fato, mas em que ela consiste (BEUREN, 2003).

Quanto à lógica de pesquisa, o estudo caracteriza-se como indutivo, pois, conforme Gray (2012), é por meio da coleta e análise de dados que o pesquisador estabelece relações entre variáveis e teorias, além de que a partir de constatações por meio da observação ou dados se chega a preposições gerais (RICHARDSON, 2007). 
A abordagem do problema é feita de forma qualitativa, pois visa identificar a opção de compras de ações com sua efetiva aplicabilidade por meio do pronunciamento técnico CPC 10 (R1), sem a utilização de ferramentas estatísticas (GIL, 2002; BEUREN, 2003). Descreve a complexidade de determinado problema, analisa a interação de certas variáveis, compreende e classifica processos dinâmicos vividos por grupos sociais (RICHARDSON, 2007).

A tipologia de pesquisa quanto ao procedimento é do tipo documental, para Lopes (2006, p. 220), a abordagem documental “[...] é baseada em materiais que ainda não receberam um tratamento analítico ou que podem ser reelaborados de acordo com os objetivos da pesquisa". Portanto, utilizaram-se dados secundários, uma vez que as informações já receberam algum tipo de tratamento analítico (GIL, 1999; GRAY, 2012).

\section{2 POPULAÇÃO E AMOSTRA}

A população do estudo é formada por 150 empresas listadas nas revistas Você S/A, no período entre 2010 e 2012; o objetivo final da amostra é atender aos requisitos: assiduidade; listadas na BM\&FBOVESPA; aplicar em sua organização o plano de remuneração variável baseado em opção de compras de ações.

Inicialmente, as 150 empresas classificadas como "as melhores empresas para você trabalhar" pela revista Você S/A, publicadas nos anos 2010, 2011 e 2012, foram selecionadas. Com base nesses dados, foi inserido um filtro de assiduidade, ou seja, restringiu-se a amostra para aquelas empresas que se mantiveram na listagem durante os três anos analisados.

Nessa primeira seleção, 59 empresas foram identificadas como assíduas. Após o primeiro resultado, novo critério seletivo foi aplicado, fazendo-se uma análise por intermédio da BM\&FBOVESPA para identificação das empresas de capital aberto; por meio deste filtro foram encontradas nove empresas. Como resultado deste filtro as seguintes empresas continuaram na amostra, conforme Quadro 3.

Quadro - 3 Empresas de capital aberto listadas na BM\&FBovespa

\begin{tabular}{|l|l|l|}
\hline \multicolumn{2}{|l|}{ Empresas } & Setor \\
\hline 1 & Bradesco & \multirow{2}{*}{ Bancos e Serviços Financeiros } \\
\hline 2 & Cielo & \\
\hline 3 & Coelce & Energia \\
\hline 4 & Ecorodovias & Transporte e Logística \\
\hline
\end{tabular}




\begin{tabular}{|l|l|l|}
\hline 5 & Embraer & \multirow{2}{*}{ Autoindústria } \\
\hline 6 & Fras-Le & \\
\hline 7 & Gerdau & Metalúrgica e Siderúrgica \\
\hline 8 & Magazine Luiza & Varejo \\
\hline 9 & Whirpool (Embraco) & Indústria \\
\hline
\end{tabular}

Fonte: os autores.

Pode-se considerar que da amostra inicial, as empresas de capital aberto representam apenas $6 \%$ das empresas listadas na BM\&FBOVESPA. Para a conclusão da amostra, faz-se necessário analisar individualmente, entre as empresas de capital aberto listadas na BM\&FBOVESPA, quais contemplam seus colaboradores com a remuneração variável baseada na opção de compras de ações. Para isso, foram colhidas as demonstrações contábeis, das nove empresas e analisadas individualmente quais aplicavam o plano. Assim, foram evidenciadas, no Quadro 4, por meio das demonstrações contábeis, que as seguintes empresas optam pelo plano de compra de ações:

Quadro 4 - Empresas com plano de opção de compra de ações

\begin{tabular}{|l|l|l|l|l|}
\hline Empresas & Possui Pca & 2010 & 2011 & 2012 \\
\hline Bradesco & Não & - & - & - \\
\hline Cielo & Sim & $\sqrt{ }$ & $\sqrt{ }$ & $\sqrt{ }$ \\
\hline Coelce & Não & - & - & - \\
\hline Ecorodovias & Não & - & - & - \\
\hline Embraer & Sim & $\sqrt{ }$ & $\sqrt{ }$ & $\sqrt{ }$ \\
\hline Fras-Le & Não & - & - & - \\
\hline Gerdau & Sim & $\sqrt{ }$ & $\sqrt{ }$ & $\sqrt{ }$ \\
\hline Magazine Luiza & Não & - & - & - \\
\hline Whirpool (Embraco) & Sim & $\sqrt{ }$ & $\sqrt{ }$ & $\sqrt{ }$ \\
\hline Fonte: os a & &
\end{tabular}

Fonte: os autores.

Contemplando o plano de compra de ações da amostra, foram encontradas quatro empresas: Cielo, Embraer, Gerdau e Whirpool (Embraco). A partir dessa identificação, foi considerado que apenas 2,67\% das 150 melhores empresas para você trabalhar indicadas pela revista Você S/A, publicadas nos anos 2010, 2011 e 2012, possuem esse tipo de remuneração variável.

Com a amostra definida, foram coletadas as demonstrações financeiras padronizadas (DFP) e as notas explicativas para identificar por meio desses 
documentos o cumprimento dos procedimentos para divulgação das informações, constantes no CPC 10 (R1).

\section{ANÁLISE DOS RESULTADOS}

Nesta seção, é apresentada a evidenciação dos dados, referente aos itens de divulgação do CPC 10 (R1), item n. 45, bem como a análise e a verificação do cumprimento deles. Sequencialmente, são apresentadas considerações sobre o resultado encontrado nesta pesquisa e em pesquisas correlatas.

\section{1 EVIDENCIAÇÃO DOS DADOS}

A seguir serão demonstrados os itens de divulgação expostos no CPC 10 (R1), item n. 45. Tais informações estão subdivididas conforme Quadro 1 desta pesquisa. Para exemplificar o que é solicitado pelo CPC 10 (R1), foram extraídos trechos das Demonstrações Financeiras Padronizadas (DFP) das empresas com plano de opções de compra de ações, do período de 2010 a 2012. A escolha dos trechos das Demonstrações Financeiras Padronizadas (DFPs) das empresas ocorreu pelo requisito de qualidade e detalhamento da informação. No Quadro 5, é possível verificar o item a.1, referente aos que podem participar do plano de opções de compra de ações.

Quadro 5 - Requisitos de aquisição da opção de ações

\begin{tabular}{|l|l|}
\hline Item & Subitem \\
\hline $\begin{array}{l}\text { a) Descrição de cada tipo de acordo com pagamento baseado } \\
\text { em ações que vigorou em algum momento do período, } \\
\text { incluindo, para cada acordo, os termos e condições gerais. }\end{array}$ & $\begin{array}{l}\text { 1) Requisitos de aquisição } \\
\text { de direito. }\end{array}$ \\
\hline
\end{tabular}

Fonte: adaptado de CPC 10 (R1), item n. 45.

Tal item foi atendido pelas empresas, conforme trechos expostos sequencialmente:

Em Assembleia Geral Extraordinária realizada em 19 de abril de 2010, na sede da Companhia, foi aprovado o "Programa para a outorga de opções de compra de ações", destinado a diretores e empregados da Companhia ou de suas controladas e que tenham pelo menos dois anos de vínculo de trabalho. A aquisição do direito de exercício das opções se dá em três mo- 
mentos como segue: I) $20 \%$ após $1^{\circ}$ ano, II) $30 \%$ após o $2^{\circ}$ ano e III) $50 \%$ após o $3^{\circ}$ ano, sempre em relação à data da outorga de cada opção. (EMBRAER, 2012, grifo nosso).

O mesmo item foi relatado pela Companhia Gerdau na DFP de 2012.

A Assembleia Geral Extraordinária da Gerdau S.A. de 30/04/2003 decidiu, com base em plano previamente aprovado e dentro do limite do capital autorizado, outorgar opção de compra de ações preferenciais aos administradores, empregados ou pessoas naturais que prestem serviços à Companhia ou às sociedades sob seu controle [...] O Plano de Opções prevê que $75 \%$ das opções outorgadas a administradores apenas serão exercíveis se forem atendidas as metas de desempenho estabelecidas para o período pelo Comitê Executivo. (GERDAU, 2012, grifo nosso).

Dessa forma, as empresas esclarecem sobre os possíveis beneficiários do plano de opções de ações, bem como o processo de aquisição de tal direito. No Quadro 6 é apresentado sobre a validade das opções de ações.

Quadro 6 - Validade das opções de ações

\begin{tabular}{|l|l|}
\hline Item & Subitem \\
\hline a) Descrição de cada tipo de acordo com pagamento basea- & 2) Prazo Máximo das Op- \\
do em ações que vigorou em algum momento do período, \\
incluines Outorgadas.
\end{tabular}

Fonte: adaptado de CPC 10 (R1), item n. 45.

Exemplificando o requerido pelo item a. 2:

O programa de Incentivo de Longo Prazo da Companhia garante o alinhamento dos executivos com a estratégia e os indicadores de desempenho de longo prazo [...] A concessão é feita anualmente, e possui um ciclo de 3 anos para ficar disponível, com o objetivo de retenção dos profissionais. (WHIRLPOOL S.A., 2011, grifo nosso).

O mesmo item foi relatado pela Companhia Cielo na DFP de 2012 da seguinte forma:

Em $1^{\mathrm{o}}$ de junho de 2009, foi realizada a Assembleia Geral Extraordinária que ratificou a aprovação do plano de opção de compra de ações ordinárias de emissão da Sociedade, que tem vigência de dez anos a partir da data da primeira outorga aos beneficiários. (CIELO, 2012, grifo nosso). 
Observa-se que o prazo máximo das opções outorgadas é variável para cada empresa, e ainda justificado por uma delas que o objetivo é a retenção do profissional. No Quadro 7, é possível a verificação de como ocorre a liquidação das opções de ações.

Quadro 7 - Liquidação das opções de ações

\begin{tabular}{|c|c|}
\hline Item & Subitem \\
\hline $\begin{array}{l}\text { a) Descrição de cada tipo de acordo com pagamento basea- } \\
\text { do em ações que vigorou em algum momento do período, } \\
\text { incluindo, para cada acordo, os termos e condições gerais. }\end{array}$ & $\begin{array}{l}\text { 3) Método de liquidação } \\
\text { (caixa ou instrumentos patri- } \\
\text { moniais). }\end{array}$ \\
\hline
\end{tabular}

Fonte: adaptado de CPC 10 (R1), item n. 45.

Elucidando tal subitem:

A Companhia efetua a liquidação deste plano de benefício entregando ações de sua própria emissão, que são mantidas em tesouraria até o efetivo exercício das opções por parte dos empregados. Durante os exercícios findos em 31 de dezembro de 2011 e 2010, os efeitos reconhecidos no resultado referentes aos prêmios em opções liquidadas em ações foram de US $\$ 0,8$ milhão (R \$ 1,3 milhão) e US \$ 2,7 milhões ( $\mathrm{R}$ \$ 4,8 milhões), respectivamente. Durante os exercícios findos em 31 de dezembro de 2011 e 2010, os efeitos reconhecidos no resultado referentes aos prêmios em opções liquidados em dinheiro foram de US\$ 8,6 milhões R \$ 14,4 milhões e US\$ 9,3 milhões ( $\mathrm{R} \$ 16,4$ milhões), respectivamente. (GERDAU, 2011, grifo nosso).

Portanto, para a empresa, as ações permanecem em tesouraria, tal prática foi executada no período de 2010 a 2012. No Quadro 8 são elencados os possíveis grupos de ações que devem ser apresentados pela companhia além do preço médio ponderado de tais grupos de opção de ações.

Quadro 8-Grupos de opções de ações

\begin{tabular}{|l|l|}
\hline \multirow{4}{*}{ Item } & Subitem \\
\hline \multirow{4}{*}{$\begin{array}{l}\text { b) A quantidade e o preço médio pon- } \\
\text { derado de exercício das opções para cada } \\
\text { um dos seguintes grupos: }\end{array}$} & 1) em circulação no início do período; \\
\cline { 2 - 2 } & 2) outorgadas durante o período; \\
\cline { 2 - 2 } & 4) exercidas durante o período; \\
\cline { 2 - 2 } & 5) expiradas durante o período; \\
\hline & 6) em circulação no final do período; \\
\hline & 7) exercíveis no final do período. \\
\hline
\end{tabular}

Fonte: adaptado de CPC 10 (R1), item n. 45. 
Relato da Companhia Embraer sobre o item supracitado:

Em 30 de abril de 2010, foram outorgadas opções de compra de 6.510 .000 ações, às quais foi atribuído um preço de exercício de $\mathrm{R} \$ 10,19$ por ação. O valor justo, atribuído a essas opções foi determinado com base no modelo de precificação Black \& Scholes, onde o valor de cada opção foi calculado em R\$ 1,77 para o lote com início de direito de exercício ao final do primeiro ano, $\mathrm{R} \$ 2,74$ para lote com início de direito de exercício ao final do segundo ano e $\mathrm{R} \$ 3,44$ para o lote com início de direito de exercício ao final do terceiro ano [...] Vale destacar que o tempo a decorrer até o exercício foi mensurado conforme decisão da administração e considera o final do período de carência como base para o cálculo, ou seja, as opções foram calculadas com os prazos de exercício determinados de um ano, dois anos e três anos. Essa premissa foi adotada, pois a administração entende que o exercício da opção ocorrerá ao final de cada período de carência devido à alta liquidez ao alto ganho previsto para cada ação. (EMBRAER, 2010).

Quadro 9 - Ações Embraer em 2010

\begin{tabular}{|l|l|l|}
\hline \multirow{2}{*}{} & \multicolumn{2}{|l|}{2010} \\
\cline { 2 - 3 } & Ações (milhares) & Preço médio $(\mathrm{R} \$)$ \\
\hline Em aberto no início do exercício & - & - \\
\hline Outorgas & 6.51 & 10.19 \\
\hline Posição ao fim do exercício & 6.51 & 10.19 \\
\hline
\end{tabular}

Fonte: Embraer (2010).

O mesmo item também foi relatado na DFP da Companhia Cielo, de 2012.

Tabela 1 - Detalhamento das opções de ações Cielo em 2012

(continua)

\begin{tabular}{llllllll}
\hline & & & & & $\begin{array}{l}\text { Preço de } \\
\text { exercício }\end{array}$ & $\begin{array}{l}\text { Valor justo } \\
\text { das opções }\end{array}$ \\
\hline $\begin{array}{l}\text { Data de } \\
\text { outorga }\end{array}$ & $\begin{array}{l}\text { Outorga- } \\
\text { das }\end{array}$ & $\begin{array}{l}\text { Cancela- } \\
\text { das }\end{array}$ & Exercidas & $\begin{array}{l}\text { Bonifica- } \\
\text { ção }\end{array}$ & Saldo & (R \$ p/ ação) & (R \$ p/ ação) \\
$\begin{array}{l}\text { Julho de } \\
2009\end{array}$ & 1.042 .320 & -90.596 & -948.230 & 68.717 & 72.211 & 23,69 & 10,43 \\
$\begin{array}{l}\text { Setem- } \\
\text { bro de }\end{array}$ & & & & & & & \\
2009 & 220.480 & -55.335 & -142.482 & 40.505 & 63.168 & 35,32 & 13,75 \\
\hline
\end{tabular}


Amanda Mendieta Larini et al.

\begin{tabular}{llllllll}
\hline & & & & & & (conclusão) \\
\hline $\begin{array}{l}\text { Data de } \\
\text { outorga }\end{array}$ & $\begin{array}{l}\text { Outorga- } \\
\text { das }\end{array}$ & $\begin{array}{l}\text { Cancela- } \\
\text { das }\end{array}$ & Exercidas & $\begin{array}{l}\text { Bonifica- } \\
\text { ção }\end{array}$ & Saldo & (R\$ p/ ação) & (R\$ p/ ação) \\
$\begin{array}{l}\text { Julho de } \\
2010\end{array}$ & 1.073 .680 & -279.307 & -532.777 & 163.314 & 424.910 & 33,33 & 13,38 \\
$\begin{array}{l}\text { Julho de } \\
2011\end{array}$ & 1.315 .854 & 164.970 & -7.132 & 262.413 & 1.406 .165 & 26,05 & 12,48 \\
$\begin{array}{l}\text { Fevereiro } \\
\text { de } 2012\end{array}$ & 96.850 & - & - & 19.369 & 116.219 & - & 52,28 \\
$\begin{array}{l}\text { Julho de } \\
2012\end{array}$ & 987.487 & -7.703 & -6.838 & - & 972.946 & 44,48 & 18,34 \\
Total & 4.736 .671 & 597.911 & -1.637 .459 & 554.318 & 3.055 .619 & & \\
\hline
\end{tabular}

Fonte: Cielo (2012).

O item supracitado demonstra a transparência da informação para os usuários interessados, com maior detalhamento de todas as opções de ações já emitidas pela companhia.

O Quadro 10 detalha a forma como devem ser evidenciados os preços das ações exercidas.

Quadro 10 - Preço das ações

\begin{tabular}{|c|c|}
\hline Item & Subitem \\
\hline \multirow{2}{*}{$\begin{array}{l}\text { c) Para as opções de ações exercidas durante o período, o preço } \\
\text { médio ponderado das ações na data do exercício. } \\
\text { Se as opções forem exercidas em base regular durante todo o } \\
\text { período, a entidade pode, em vez disso, divulgar o preço médio } \\
\text { ponderado das ações durante o período. }\end{array}$} & $\begin{array}{l}\text { 1) preço médio } \\
\text { ponderado na data do } \\
\text { exercício; }\end{array}$ \\
\hline & $\begin{array}{l}\text { 2) preço médio } \\
\text { ponderado durante o } \\
\text { período. }\end{array}$ \\
\hline
\end{tabular}

Fonte: adaptado de CPC 10 (R1), item n. 45.

Os preços médios ponderados das ações foram divulgados em uma tabela resumo pela empresa Whirlpool S.A. na DFP de 2012

A tabela a seguir apresenta a movimentação das opções de ações durante o exercício de 2012 e 2011 : 
Tabela 2 - Movimentação das opções de ações Whirpool em 2011 e 2012

\begin{tabular}{lll}
\hline & $\begin{array}{l}\text { Número de opções } \\
\text { (em milhares) }\end{array}$ & $\begin{array}{l}\text { Média ponderada do preço de } \\
\text { exercício (US\$) }\end{array}$ \\
\cline { 2 - 3 } Opções em aberto em 10/01/2011 & 261 & 61,97 \\
Outorgadas & 64 & 85,45 \\
Exercidas & -17 & 41,54 \\
Perda do direito ou prescritas & -20 & 75,07 \\
Opções em aberto em 31/12/2011 & 288 & 67,51 \\
Opções exercíveis em 31/12/2011 & 192 & 68,92 \\
\hline & Número de opções & Média ponderada do preço de \\
& $($ exercício (US $\$$ )
\end{tabular}

Fonte: Whirlpool S.A. (2012).

Nota: O valor intrínseco das opções de ações em 2012 e 2011 foram US \$ 2 milhões e US \$1 milhão, respectivamente. Não houve benefício fiscal decorrente destas transações. O valor recebido das opções de ações exercidas em 2012 e 2011 foram de US 3 milhões e US \$ 1 milhão, respectivamente. A média ponderada remanescente da cláusula contratual das opções de ações em 31 de dezembro de 2012 é de 5,9 anos (5,8 anos em 31 de dezembro de 2011).

O mesmo item também foi relatado na DFP da Companhia Gerdau em 2012.

Tabela 3 - Resumo da movimentação do plano de incentivo de longo prazo

\begin{tabular}{|c|c|c|c|c|c|c|c|c|}
\hline & & & & & & & & $\begin{array}{l}\text { Quantidade } \\
\text { de ações }\end{array}$ \\
\hline $\begin{array}{l}\text { Ano da } \\
\text { outorga }\end{array}$ & $\begin{array}{l}\text { Preço de } \\
\text { exercício } \\
\text { - R\$ }\end{array}$ & $\begin{array}{l}\text { Prazo de } \\
\text { Carência }\end{array}$ & $\begin{array}{l}\text { Preço } \\
\text { Médio de } \\
\text { mercado } \\
\text { acumula- } \\
\text { do (1) }\end{array}$ & $\begin{array}{l}\text { Saldo } \\
\text { Inicial em } \\
31 / 12 / 2011\end{array}$ & $\begin{array}{l}\text { Outorga- } \\
\text { das }\end{array}$ & Expiradas & Exercidas & $\begin{array}{l}\text { Saldo } \\
\text { final em } \\
31 / 12 / 2012\end{array}$ \\
\hline 2004 & 6,78 & 5 anos & 17,85 & 878.364 & - & - & -74.846 & 803.518 \\
\hline 2005 & 10,58 & 3 anos & 17,85 & 375.028 & - & - & 18.123 & 356.905 \\
\hline 2005 & 10,58 & 5 anos & 17,85 & 842.098 & - & - & 70.728 & 771.370 \\
\hline 2006 & 12,86 & 5 anos & 17,85 & 1.521 .126 & - & - & 87.186 & 1.433 .940 \\
\hline 2007 & 17,50 & 5 anos & 17,85 & 1.247.129 & - & - & 48.565 & 1.198 .564 \\
\hline 2008 & 26,19 & 5 anos & 17,85 & 1.052 .812 & - & 43.134 & - & 1.009 .678 \\
\hline
\end{tabular}


Amanda Mendieta Larini et al.

\begin{tabular}{|c|c|c|c|c|c|c|c|c|}
\hline 2009 & 14,91 & 5 anos & 17,85 & 2.101 .178 & - & 48.559 & -62.592 & 1.990 .027 \\
\hline 2010 & 29,12 & 5 anos & 17,85 & 1.572 .819 & - & 69.075 & -3.646 & 1.500 .098 \\
\hline 2011 & 22,61 & 5 anos & 17,85 & 1.397 .410 & & 168.687 & -8.621 & 1.220 .102 \\
\hline \multirow[t]{2}{*}{2012} & 14,42 & 5 anos & 17,85 & - & 2.277 .080 & 109.699 & 10.203 & 2.157.178 \\
\hline & & & & 10.987 .964 & 2.277 .080 & -439.154 & -384.510 & 12.441 .380 \\
\hline \multicolumn{9}{|c|}{ (1) cotação média acumulada da ação no período } \\
\hline & & & & & & & & $\begin{array}{l}\text { Quantidade } \\
\text { de ações }\end{array}$ \\
\hline $\begin{array}{l}\text { Ano da } \\
\text { outorga }\end{array}$ & $\begin{array}{l}\text { Preço de } \\
\text { exercício } \\
\text { - R\$ }\end{array}$ & $\begin{array}{l}\text { Prazo de } \\
\text { Carência }\end{array}$ & $\begin{array}{l}\text { Preço } \\
\text { Médio de } \\
\text { mercado } \\
\text { acumula- } \\
\text { do (1) }\end{array}$ & $\begin{array}{l}\text { Saldo } \\
\text { Inicial em } \\
31 / 12 / 2011\end{array}$ & $\begin{array}{l}\text { Outorga- } \\
\text { das }\end{array}$ & Expiradas & Exercidas & $\begin{array}{l}\text { Saldo } \\
\text { final em } \\
31 / 12 / 2011\end{array}$ \\
\hline 2004 & 6,78 & 5 anos & 16,92 & 988.582 & - & - & & \\
\hline 2005 & 10,58 & 3 anos & 16,92 & 388.468 & - & - & & \\
\hline 2005 & 10,58 & 5 anos & 16,92 & 932.681 & - & - & & \\
\hline 2006 & 12,86 & 5 anos & 16,92 & 1.624 .621 & - & - & & \\
\hline 2007 & 17,50 & 5 anos & 16,92 & 1.280 .299 & - & -25.028 & & \\
\hline 2008 & 26,19 & 5 anos & 16,92 & 1.083 .020 & - & -30.208 & & \\
\hline 2009 & 14,91 & 5 anos & 16,92 & 2.169 .970 & - & 58.728 & & \\
\hline 2010 & 29,12 & 5 anos & 16,92 & 1.607 .567 & - & -32.467 & & \\
\hline \multirow[t]{2}{*}{2011} & 22,61 & 5 anos & 16,92 & - & 1.444 .131 & -39.984 & & \\
\hline & & & & 10.075 .208 & 1.444 .131 & -186.415 & & \\
\hline
\end{tabular}

(1) cotação média acumulada da ação no período

Fonte: Gerdau (2012).

O item c, Quadro 8, também detalha o preço das ações para permitir transparência e conhecimento do cálculo efetivo utilizado na ponderação das ações.

\section{2 CONSIDERAÇÕES}

Com base nas informações coletadas, podemos observar a importância da aplicação e a constante atualização das organizações em relação à remuneração variável. Na amostra final, delas de capital aberto listadas na BM\&FBOVESPA, foi possível identificar que $44,44 \%$ das empresas aplicam a remuneração variável com base na opção de compras de ações.

Portanto, quase metade das organizações identificadas neste estudo tem aplicado o plano de remuneração variável baseado na compra de ações. Um fator que pode ter contribuído é a assiduidade; por se tratar de um plano de longo prazo, 
as empresas acabam por ser fiéis a sua manutenção e aprimoramento. Os resultados apresentados remetem à preocupação que as organizações estão demonstrando com os indivíduos que trabalham em prol da organização. Hipólito (2001) corrobora com essa ideia, esclarecendo que as necessidades antes atendidas pela remuneração tradicional, nos dias de hoje, estão sendo alteradas.

O estudo similar realizado por Dias, Cunha e Mário (2009) subdividiu em oito os itens necessários para a evidenciação da opção de compra por ações, conforme os requisitos determinados pelo CPC 10 e no Ofício-Circular/CVM/SNC/SEP n. 01/2007. Após analisadas as demonstrações financeiras e as notas explicativas das 12 empresas dos setores de bens industriais, construção e transporte, consumo cíclico, consumo não cíclico, materiais básicos, tecnologia da informação, financeiro e outros, eles concluíram que após o surgimento do CPC 10 o disclosure passou a ser superior.

Os autores demonstraram que em 2007 apenas 32,29\% das informações foram evidenciadas, enquanto em 2008 esse número subiu para 44,79\%; o único item que não apresentou melhora foi a descrição de eventuais negociações envolvendo ações em tesouraria para efetuar o resgate das opções.

A presente pesquisa, realizada após a aprovação do CPC 10 (R1), bem como o estudo de Dias, Cunha e Mário (2009), teve como objetivo verificar a evidenciação de informações referentes à remuneração por opção de compra de ações. Os resultados corroboram, em partes, com o estudo dos referidos autores. No entanto, a presente pesquisa identificou uma preocupação de atendimento às normas por parte das empresas estudadas. Os resultados de ambos os estudos, no entanto, demonstram que a evidenciação se tornou maior a partir do Pronunciamento Técnico de 10.

Com base nas análises realizadas neste estudo, constatou-se que:

a) o entendimento do pronunciamento técnico CPC 10 (R1) possibilitou a identificação de seus objetivos e dos itens necessários para seu atendimento, tornando-se mais acessível à busca por respostas e análises;

b) foi constatado, por meio das demonstrações contábeis, que as solicitações do pronunciamento técnico CPC 10 (R1), quanto aos procedimentos para divulgação das informações, foram atendidas no período de 2010 a 2012, pela amostra estudada;

c) observa-se que, quanto aos itens requeridos pelo CPC 10 (R1), item n. 45, o método de liquidação das opções de ações é um subitem que não está plenamente claro nas notas explicativas das empresas e que deve ser 
melhor explorado por elas, pois se trata de uma informação relevante que contribui para a totalidade da transparência das informações requeridas. Nesse caso, cabe um destaque para a Companhia Gerdau que melhor evidenciou tal requisito;

d) o modelo utilizado em 2012 para precificação das ações na mensuração do valor justo para o plano de remuneração variável com a compra de opções de ações é o Black-Scholes. Para os anos anteriores, nas empresas que não utilizaram tal método, há uma explicação do cálculo empregado;

e) a utilização da remuneração variável baseada na compra de ações, é pioneira, entre as quatro empresas analisadas pela Companhia Gerdau S.A. que incorporou tal prática em 2004, ou seja, antes da regulamentação estabelecida pelo CPC 10 (R1);

f) ainda que não haja um crescimento sequencial no período analisado quanto à quantidade emitida de ações, observa-se que as empresas apresentam uma valoração das ações quando comparado 2010 a 2012.

Ainda que o cumprimento da evidenciação das informações seja atendido, é necessária a constante verificação das demonstrações contábeis e também a atualização dos procedimentos para que as transações com remuneração baseada em compra de ações sejam transparentes aos colaboradores e aos usuários das informações.

\section{CONCLUSÕES E RECOMENDAÇÕES}

A presente pesquisa teve como objetivo identificar quais empresas, entre as 150 melhores para se trabalhar, conforme a revista Você S.A., ofereciam a opção de compra de ações como remuneração variável a seus funcionários, bem como se elas atendiam ao exigido pelo item n. 45 do CPC 10 (R1). Para isso, foram selecionadas as empresas listadas na BM\&FBOVESPA, totalizando nove empresas. Posteriormente analisadas suas demonstrações financeiras, bem como as notas explicativas para identificar quais optavam pelo plano de remuneração por opção de ações; apenas quatro empresas contemplam tal sistema no período de 2010 a 2012: Cielo, Embraer, Gerdau e Embraco.

Quanto ao efetivo cumprimento do Pronunciamento Técnico, portanto, foi possível inferir, por meio da devida análise das demonstrações contábeis e notas 
explicativas, que as organizações analisadas cumpriram parcialmente os requisitos abordados no item n. 45 do CPC 10 (R1), corroborando com o estudo desenvolvido anteriormente por Dias, Cunha e Mário (2009), no qual os autores demonstraram que o nível de evidenciação sobre planos de opções em ações foi superior após a divulgação do CPC 10.

Destaca-se que as empresas apresentam informações além das requisitadas pelo CPC 10 (R1), evidenciando que, além do cumprimento da regulamentação sobre tal premissa, há necessidade e interesse de informação transparente perante os usuários interessados. Ressalta-se que o item que dispõe sobre o método de liquidação da opção de ações pode ser melhor evidenciado para que não haja dúvidas quanto a esse preceito.

O disclosure das empresas quanto à remuneração por compra de ações demonstra que o processo tem sido executado de forma objetiva em notas explicativas e em consonância com as regras estabelecidas pelo CPC, o que pode proporcionar confiabilidade para os funcionários que possuem tal remuneração variável. Com a realização desta pesquisa, foi possível, também, encontrar lacunas que são sugeridas como agenda para estudos posteriores: motivos pelos quais as empresas adotam este sistema de remuneração variável; e relação entre o nível de disclosure das opções de ações e a governança corporativa (MELIS; CARTA, 2010; NELSON; GALLERY; PERCY, 2010; VICTOR; TERRA; SCHIEHLL, 2013; ALI, 2014) nas empresas brasileiras.

Ressalta-se, ainda, que outros critérios considerados importantes por funcionários podem ser adicionados na análise do nível de evidenciação sobre a opção de ações por parte das empresas, já que o presente estudo se limitou às variáveis estabelecidas pelo item n. 45 do CPC 10 (R1).

\section{REFERÊNCIAS}

ALI, C. B. Corporate Governance, Principal-Principal Agency Conflicts, And Disclosure. Journal of Applied Business Research (JABR), v. 30, n. 2, p. 419432, 2014.

\section{BEUREN, I. M. et al. Como Elaborar Trabalhos Monográficos em}

Contabilidade: teoria e prática. São Paulo: Atlas, 2003.

BEUREN, I. M.; KAVESKI, I. D. S.; RIGO, V. P. Associação das medidas de desempenho para pagamento de bônus aos executivos com dependência de capital humano. Revista Contemporânea de Contabilidade, v. 11, n. 22, p. 3-24, 2014. 
BRASIL. Lei n. 6.404, de 15 de dezembro de 1976. Sociedade por Ações. Diário Oficial da União, Brasília, DF, 15 dez. 1976. Disponível em < http://www. planalto.gov.br/ccivil_03/leis/L6404compilada.htm>. Acesso em: 18 jul. 2013.

BROCKMAN, P.; MARTIN, X.; PUCKETT, A. Voluntary disclosures and the exercise of CEO stock options. Journal of Corporate Finance, v. 16, n. 1, p. 120-136, 2010.

CARVALHO NETO, A. A negociação da participação nos lucros e resultados: estudo em quatro setores dinâmicos da economia brasileira. Revista de Administração Contemporânea, Curitiba, v. 5, n. 1, p. 195-214, jan./abr. 2001.

CIELO. Nossa História. São Paulo, 2013. Disponível em: < http://www.cielo. com.br/portal/home.html>. Acesso em: 18 jun. 2013.

COMISSÃO DE VALORES MOBILIÁRIOS. Deliberação CVM 562/2008. Rio de Janeiro: CVM, 2008. In: CVM. Comissão de Valores Mobiliários. Disponível em: <http://www.cvm.gov.br/asp/cvmwww/atos/Atos_Redir. asp ? Tipo $=$ D\&File $=\backslash$ deliideli562.doc $>$. Acesso em: 18 jul. 2013.

COMITÊ DE PRONUCIAMENTOS CONTÁBEIS. CPC 10 (R1) - Pagamento baseado em ações. Brasília: CPC, 2010. In: CPC. Comitê de Pronunciamentos Contábeis. Disponível em: < http:// www.cpc.org.br/pdf/CPC10_R1.pdf>. Acesso em: 18 jun. 2013.

COMITÊ DE PRONUNCIAMENTOS CONTÁBEIS. Conheça o CPC. Brasília: CPC, 2013. In: CPC. Comitê de Pronunciamentos Contábeis. Disponível em: <http://www.cpc.org.br/oque.htm>. Acesso em: 18 jun. 2013.

DIAS, W. O.; CUNHA, J. V. A. da; MÁRIO, P. do C. Plano de incentivo em opção de ações e a harmonização contábil: estudo do nível de disclosure das empresas brasileiras após o CPC 10. Pensar Contábil, Rio de Janeiro, v. 11, n. 46, p. 29-38, out./dez. 2009.

EMBRACO. Conheça a Embraco. Perfil e História. Joinville, 2013. Disponível em: < http://www.embraco.com/default.aspx?tabid=77>. Acesso em: 13 jun. 2013.

EMBRAER. Conheça a Embraer. Tradição e História. São Paulo, 2013.

Disponível em: <http://www.embraer.com.br/pt-BR/ConhecaEmbraer/ TradicaoHistoria/Paginas/Home.aspx> . Acesso em: 17 jun. 2013.

ESPAHBODI, H. et al. Stock price reaction and value relevance of recognition versus disclosure: the case of stock-based compensation. Journal of Accounting and Economics, v. 33, n. 3, p. 343-373, 2002. 
GALDI, F. C.; CARVALHO, L. N. Remuneração em opções de ações: o SFAS 123 revisado. Revista Contabilidade e Finanças, edição comemorativa, São Paulo, p. 23-35, set. 2006 .

GERDAU. Notas explicativas, 2012.

GIL, A. C. Como Elaborar Projetos de Pesquisa. 4. ed. São Paulo: Atlas, 1999.

GRAY, D. E. Pesquisa no Mundo Real. Porto Alegre: Penso, 2012.

HALL, B. J. What you need to know about stock options. Harvard Business Review, Boston, v. 78, n. 2, p. 121-129, Mar./Apr., 2000.

HIPÓLITO, J. A. M. Administração salarial: a remuneração por competências como diferencial competitivo. São Paulo: Atlas, 2001.

HUDDART, S.; LANG, M. Employee stock option exercises an empirical analysis. Journal of Accounting and Economics, v. 21, n. 1, p. 5-43, 1996.

KRAUTER, E. A Remuneração de executivos baseada em opções de ações indexadas ao IBOVESPA e a criação de valor para o acionista. In: SEMEAD, São Paulo, 2006. Anais Eletrônicos... São Paulo, 2006. Disponível em: < http:// www.ead.fea.usp.br/semead/9semead/resultado_semead/an_resumo.asp?cod_ trabalho $=122>$. Acesso em: 17 jun. 2013.

LOPES, J. O fazer do trabalho científico em ciências sociais aplicadas. Recife: Universitária, 2006.

MADRID, E. M.; OCHOVO, R. B.; PEÑALVER, J. F. S. Tratamento contábil de las stock options segúnla normativa contable internacional. Contaduría y Administración, n. 230, p. 105-129, jan./abr. 2010.

MARCON, R.; GODO, C. K . Desempenho financeiro das empresas e remuneração por stock options: um estudo multissetorial. Revista de Administração FACES, Belo Horizonte, v. 3, n. 1, jan./jun. 2004.

MARQUART, A. Análise das características da remuneração variável nas 100 maiores empresas de SC. Dissertação (Mestrado)-Universidade Federal de Santa Catarina, Florianópolis, 2009.

MARRAS, J. P. Administração da remuneração: remuneração tradicional e estratégica: elementos de estatística aplicada: normas legais: benefícios. São Paulo: Pioneira Thomson Learning, 2002. 
MELIS, A.; CARTA, S. Does accounting regulation enhance corporate governance? Evidence from the disclosure of share-based remuneration. Journal of Management \& Governance, v. 14, n. 4, p. 435-446, 2010.

NELSON, J.; GALLERY, G.; PERCY, M. Role of corporate governance in mitigating the selective disclosure of executive stock option information. Accounting\&Finance, v. 50, n. 3, p. 685-717, 2010.

NUNES, A. A. Concessão de opções de ações a funcionários: um problema contábil. Revista Brasileira de Finanças, Rio de Janeiro, v. 5, n. 1, p. 32-41, jan./ abr. 2008.

NUNES, A. A., MARQUES, J. A. V. da C. Planos de incentivos baseados em opções de ações: uma exposição das distinções encontradas entre as demonstrações contábeis enviadas à CVM e à SEC. Revista Contabilidade e Finanças, São Paulo, n. 38, p. 57-73, maio/ago. 2005.

OLIVEIRA, A. F. Remuneração de Administradores e Planos de Aquisição de Ações. Comissão do Mercado de Valores Mobiliários, Lisboa. Cadernos do Mercado de Valores Mobiliários, n. 19, dez. 2004.

PEREIRA, I.; ESPERANÇA, J. P. Modelos de remuneração e rendibilidade nas empresas familiares portuguesas. Revista Portuguesa e Brasileira de Gestão, Florianópolis, v. 8, n. 1, p. 32-42, mar. 2009.

PEROBELLI, F. M. et al. Plano de opção de compra de ações e o valor da cia brasileira. Revista Brasileira de Finanças, Rio de Janeiro, v. 10, mar. 2003.

RAPPAPORT, A. Gerando valor para o acionista: um guia para administradores e investidores. São Paulo: Atlas, 2004.

RAPPAPORT, A.; MAUBOUSSIN, M. Análise de investimentos: como transformar incerteza em oportunidades lucrativas, como interpretar corretamente o preço das ações. Rio de Janeiro: Campus, 2002.

RICHARDSON, R. J. et al. Pesquisa social: métodos e técnicas. 3.ed.rev.amp. São Paulo: Atlas, 2007.

SILVEIRA JUNIOR, A.; VIVACQUA, G. Planejamento estratégico como instrumento de mudança. São Paulo: Atlas, 1996.

STREET, D. L.; CEREOLA, S. Stock option compensation: Impact of expense recognition on performance indicators of non-domestic companies listed in USA. Journal of International Accounting, Auditing and Taxation, v. 13, n. 1, p. 21-37, 2004. 
VICTOR, F. G.; TERRA, P. R. S.; SCHIEHLL, E. Determinants of voluntary executive stock option disclosure in Brazil. Journal of Management \&

Governance, v. 17, n. 2, 2013.

XAVIER, P. R. et al. Remuneração Variável: quando os resultados falam mais alto. São Paulo: Makron Books, 1999.

WOOD JÚNIOR, T. et al. Mudança Organizacional: aprofundando temas atuais em administração de empresas. 2. ed. São Paulo: Atlas, 2000.

WOOD JÚNIOR, T. Remuneração por habilidades e por competências. 3. ed. São Paulo: Atlas, 2004.

WOOD JÚNIOR, T.; PICARELLI FILHO, V. Remuneração estratégica: a nova vantagem competitiva. 3. ed. São Paulo: Atlas, 2004.

WHIRLPOOL S.A. Notas explicativas, 2012.

\section{Como citar este artigo:}

LARINI, Amanda Mendieta et al. Remuneração variável baseada no pagamento de $\leftarrow$ ações: um estudo de evidenciação das informações requeridas pelo CPC 10 (R1) $Z$ aplicado em empresas brasileiras. RACE, Revista de Administração, Contabilidade e \& Economia, Joaçaba: Ed. Unoesc, v. 14, n. 2, p. 737-768, maio/ago. 2015. Disponível em: <http://editora.unoesc.edu.br/index.php/race>. Acesso em: dia/mês/ano.

Larini, A. M., Schafer, J. D., Rosa, P. A da, \& Ferreira, L. F. Remuneração variável baseada no pagamento de ações: um estudo de evidenciação das informações

$\overleftarrow{\&}$ requeridas pelo CPC 10 (R1) aplicado em empresas brasileiras. RACE, Revista de Administração, Contabilidade e Economia, 14 (2), 737-768. Recuperado em dia/mês/ ano, de http://editora.unoesc.edu.br/index.php/race 
